\title{
Transcranial direct current stimulation in fibromyalgia: effects on pain and quality of life evaluated clinically and by brain perfusion scintigraphy*
}

\author{
Estimulação elétrica transcraniana por corrente contínua em fibromialgia: efeitos sobre a dor e \\ a qualidade de vida, avaliados clinicamente e por cintilografia de perfusão cerebral
}

Levi Higino Jales Junior ${ }^{1}$, Maria do Desterro Leiros Costa², Levi Higino Jales Neto³, João Paulo Moraes Ribeiro ${ }^{4}$, Waleska Jessiane Silva do Nascimento Freitas ${ }^{4}$, Manoel Jacobsen Teixeira ${ }^{5}$

${ }^{*}$ Received from Teaching Hospital Onofre Lopes, Federal University of Rio Grande do Norte, School of Medicine, University of São Paulo, São Paulo, SP, Brazil.

\section{ABSTRACT}

BACKGROUND AND OBJECTIVES: Transcranial Direct Current Stimulation is a neuromodulation method to treat neuropsychiatric and other diseases. This study aimed at evaluating the effect of this technique on pain and quality of life of fibromyalgia patients, in addition to studying brain images by Brain Perfusion Scintigraphy before and after procedures.

METHODS: Prospective, double-blind, randomized, controlled study with parallel arms evaluated clinically and by CT scan with single photon emission (Brain Spect). Sample was made up of 20 female fibromyalgia patients divided in two groups of 10. Parameters evaluated were quality of life by the pain Visual Analog Scale, Quality of Life Questionnaire SF-36, Fibromyalgia Impact Questionnaire and pain level measurement on tender points with Fischer's Algiometer. The effective group has received $1.0 \mathrm{~mA}$ anodal stimulation for 20 minutes in M1 to the left, cathode positioned on the right supraorbital region once a week in a total of 10 consecutive weeks. The Sham group received no electric impulses.

RESULTS: There has been decrease in the Fibromyalgia Impact Questionnaire (55.36 to 35.42; $\mathrm{p}=0.0059$ ) and the Visual Analog Scale (6.05 to 3.60; $\mathrm{p}=0.0316)$ scores. There has been statistically significant difference $(\mathrm{p}<0.05)$ in trigger points measurement in the effective group. For the effective group, the-

1. Federal University of Rio Grande do Norte, Teaching Hospital Onofre Lopes, Natal, $\mathrm{RN}$, Brazil.

2. Federal University of Paraiba, Department of Morphology, João Pessoa, PB, Brazil.

3. Hospital São Camilo, Department of Rheumatology, São Paulo, SP, Brazil.

4. Clinical Pain Center, Norte Riograndense Society for the Study of Pain, Natal, RN, Brazil.

5. University of São Paulo, School of Medicine, Clinicas Hospital, Department of Neurology, São Paulo, SP, Brazil.

Submitted in October 15, 2014.

Accepted for publication in February 09, 2015.

Conflict of interests: none - Sponsoring sources: none.

Correspondence to:

Levi Higino Jales Junior

Avenida Hermes da Fonseca, 1078 - Petrópolis

59034-000 Natal, RN, Brasil.

E-mail: ipens@supercabo.com.br

(C) Sociedade Brasileira para o Estudo da Dor re has been also evidence of statistically significant difference in the evaluation of SF-36 $(\mathrm{p}<0.05)$ in Functional Capacity, Physical and Emotional Aspects domains, where patients have increased respective indices after treatment. In Brain Spect, for 3 effective group patients, there have been significant changes in images with decreased biparietal hypoperfusion after procedures. No significant Brain Spect image changes were observed in the Sham group.

CONCLUSION: Transcranial Direct Current Stimulation was effective for therapeutic pain control and has improved quality of life of fibromyalgia patients. Brain Spect has contributed for complementary fibromyalgia evaluation.

Keywords: Chronic pain, Electric stimulation, Fibromyalgia, Neuromodulation, Scintigraphy.

\section{RESUMO}

JUSTIFICATIVA E OBJETIVOS: Estimulação Elétrica Transcraniana por Corrente Contínua é um método de neuromodulação no tratamento de doenças neuropsiquiátricas e outras. O objetivo deste estudo foi avaliar o efeito dessa técnica sobre a dor e qualidade de vida em pacientes fibromiálgicos, além de estudar imagens cerebrais por Cintilografia de Perfusão Cerebral, antes e após procedimentos.

MÉTODOS: Estudo prospectivo, duplamente encoberto, aleatório, controlado, braços paralelos, avaliados clinicamente e por tomografia computadorizada de emissão de fóton único (Spect Cerebral). Amostra constituída por 20 pacientes do gênero feminino fibromiálgicos, dois grupos de 10 , sobre dor e qualidade de vida pela Escala Analógica Visual da dor, Questionário de Qualidade de Vida-SF-36, Questionário sobre Impacto da Fibromialgia e mensuração do nível de dor em pontos sensíveis, através do Algiômetro de Fischer. $\mathrm{O}$ grupo efetivo recebeu estimulação anódica 1,0mA, 20 minutos, em M1 à esquerda, catodo posicionado na regiâo supraorbital direita, uma vez por semana perfazendo 10 semanas consecutivas. O grupo Sham não recebeu impulsos elétricos.

RESULTADOS: No grupo efetivo observou-se redução dos escores do Questionário de Impacto da Fibromialgia (55,36 para 35,42; $\mathrm{p}=0,0059)$ e da Escala Analógica Visual (6,05 para 3,$60 ; p=0,0316)$. Houve diferença estatisticamente signi- 
ficativa $(p<0,05)$ em relação aos valores mensurados dos pontos-gatilho no grupo efetivo. No grupo efetivo observou-se evidência de diferença estatisticamente significativa na avaliação do SF-36 ( $\mathrm{p}<0,05)$, quanto aos domínios de Capacidade Funcional, Aspectos Físicos e Emocionais, onde os pacientes após o tratamento aumentaram os respectivos índices estudados. No Spect Cerebral foram observadas em 3 pacientes do grupo efetivo, modificaçóes significativas nas imagens com redução da hipoperfusão biparietal observada antes do tDCS e aparecimento de novas áreas com hiperperfusão em núcleos da base, após procedimentos. No grupo Sham não foram observadas alteraçóes significativas nas imagens dos Spects Cerebrais.

CONCLUSÃO: A Estimulação Elétrica Transcraniana por Corrente Contínua foi eficaz no controle terapêutico da dor e promoveu melhora na qualidade de vida dos pacientes fibromiálgicos. O Spect Cerebral contribuiu na avaliação complementar da Fibromialgia.

Descritores: Cintilografia, Dor crônica, Estimulação elétrica, Fibromialgia, Neuromodulação.

\section{INTRODUCTION}

Fibromyalgia (FM) is a syndrome where patients refer chronic widespread pain throughout the body, associated to fatigue, sleep disorders (frequently insomnia), mood disorders (especially depression) and other clinical manifestations ${ }^{1}$.

Pain is predominantly musculoskeletal, reported as heavy and may also present as burning, jumping, "tiring" and others, in general with higher intensity at night and in the morning at awakening ${ }^{2}$. Chronic fatigue is described as lack of energy, unwillingness to work, muscle weakness and mental tiredness ${ }^{2}$. At clinical evaluation, patients are in good general status, with the presence of tender points, perceived on different parts of the body ${ }^{2}$ In 2010, new FM diagnostic criteria were established by the American College of Rheumatology (ACR) ${ }^{3}$, but previous criteria of 1990 were not invalidated. New criteria shall meet the three following conditions:

1. Widespread Pain Index (WPI) $\geq 7$ and severity symptoms (SS) in a scale of $\geq 5$ or WPI between 3 and 6 and SS with score of $\geq 9$;

2. Symptoms are present at similar level for at least three months;

3. Patients have no other disease which could justify the sensation of widespread pain ${ }^{4}$.

According to Brazilian Society of Rheumatology guidelines on Fibromyalgia (2004), treatment aims at: relieving pain, improving sleep quality and physical fitness, and decreasing fatigue, maintaining or reestablishing emotional balance and specific clinical control of associated disorders ${ }^{4}$. Notwithstanding many advances in FM understanding, its treatment is still a challenge with a constant search for evidences of effective pharmacological and non-pharmacological interventions. Low-level electric current has been suggested as a useful tool to treat neurological diseases and for the rehabilitation of chronic diseases, such as: Parkinson's disease, epilepsy, cerebrovascular diseases, stroke and several syndromes, which evolve with chronic pain $^{5}$. A study on transcranial direct current stimulation in FM patients has shown significant pain decrease ${ }^{6}$.

Aiming at bringing new knowledge or at confirming results of similar experiments, this study has evaluated the use of Transcranial Direct Current Stimulation (tDCS) in FM patients to clinically measure its effects on pain. In parallel, we have evaluated quality of life (QL) as well as we have studied brain images of those patients by brain perfusion scintigraphy (Brain Spect), before and after tDCS procedures.

\section{METHODS}

This was a prospective, double-blind, randomized and placebo-controlled study on the effects of tDCS on FM, clinically evaluated by Brain Spect. SPECT is an abbreviation for Single Photon Emission Computer Tomography, which is a specialized Nuclear Medicine exam to evaluate perfusion directly on brain blood flow, providing a pattern of human brain tissue images and which indirectly studies neuronal activities in the region ${ }^{7}$.

Data collection and applications were performed in outpatient setting by an academic and multiprofessional team trained on the use of the tDCS device, in the Norte Riograndense Institute of Health Research and Teaching (IPENS), Natal/RN.

Inclusion criteria were patients with FM, aged between 25 and 65 years, of both genders and living in the city of Natal/RN. Patients were informed about the nature of the project and have agreed in participating, allowing the recording of their activities by signing the Free and Informed Consent Term (FICT). During the whole project, in both groups, there has been no interference with the conventional treatment to which individuals were submitted, so they continued using their pharmacological and non-pharmacological therapies, according to individual situations. Exclusion criteria were patients with severe cognitive deficits; illiterate; patients with previous and/or family history of seizures; patients with arrhythmias and pacemaker; pregnant and breastfeeding females.

Patients were clinically evaluated with regard to pain characteristics and QL by the following pain evaluation methods: Visual Analog Scale (VAS); Quality of Life Questionnaire (SF-36); Fibromyalgia Impact Questionnaire (FIQ), tender point pain level measurement by Force Dial Algiometer, also known as Fischer Algiometer. All patients had their clinical history and physical evaluation recorded and attached to individual brochures. All patients included in the project were also submitted to Brain Spect before and after procedures.

Spect is a simple exam where patients are submitted to previous venous puncture and remain for 15 minutes at 
rest. Liposoluble radiotracers are injected in a forearm vein, which have the ability of crossing blood-brain barrier and concentrate inside brain cells, proportionally to blood supply, including functional demand (brain metabolism) ${ }^{8}$. This study has used the radiotracer HMPAO-99mTc (hexamethyl propylene - animaoxine marked with technetium radioisotope $)^{9,10}$. Brain images interpretation brings valuable information on blood flow in different brain regions, correlating it to the possible metabolic function of these areas, with evidences of more or less activity ${ }^{7}$. Once the radiotracer is injected, ideal brain concentration time to obtain images is 15 to 40 minutes. After this period, the tomographic study was carried out. Brain spect is contraindicated for pregnant and breastfeeding females.

In this study, Brain Spect images were analyzed and compared with the Oasis international normative database, of the Segami program ${ }^{11}$.

With regard to tDCS procedures, two electrodes were adequately positioned on the scalp of patients without causing discomfort. The design has involved 20 female participants, divided in two groups of 10 patients. One group, called effective, has received $1.0 \mathrm{~mA}$ electric impulse, supplied by an electronic unit with direct current control, from the Cerebral Electronic Stimulator equipment (CES). The other group, called Sham, has not received electric impulses. During procedures, patients remained comfortably lying down in adequate beds, with the anodal electrode positioned on the scalp, on the superior-lateral face of the skull, region corresponding to the left precentral gyrus (M1 or Brodman's area 4) on its medial third.

The cathodic electrode was positioned on the contralateral supraorbital region. Between scalp and electrode a rubber sponge was placed measuring $3 \times 5 \mathrm{~cm}$, previously moistened with $0.9 \%$ saline. Direct $1.0 \mathrm{~mA}$ current was applied during 20 minutes. For the Sham group (control), the same procedures were adopted, once a week for 20 minutes, for 10 consecutive weeks, with the fundamental difference that the tDCS device was not turned on. Patients, as well as investigator in charge and evaluators, were blind to the nature of applied stimulation; only 2 professionals knew the group to which patients belonged and the nature of applied stimulation. They recorded and filed data obtained for follow-up and analysis at the end of the sessions.

Data were recorded and filed for follow-up and scientific analysis. Pain intensity by VAS, Questionnaires (FIQ and SF-36) and tender point pain level measurement through Fischer algiometer and patients' Brain Spects, before and after treatment, were correlated.

Database was developed in XLSX format, and Excel 2010 was used to build tables, while for figures and statistical tests the free statistical software R, version 3.0.0 was used. Wilcoxon non-parametric statistical test was used to compare two paired samples ${ }^{12}$

The project was previously filed before the Plataforma Brasil and submitted to the appreciation of the Ethics and Research Committee, Teaching Hospital Onofre Lopes (CEP/
HUOL/UFRN), in compliance with Resolution 196/96 of the National Health Council and was approved by CEP/ HUOL 128183 of 10/15/2012.

Tender points pain level measured with Fischer Algiometer was carried out on classic sites, according to ACR recommendation as shown in figure 1 .

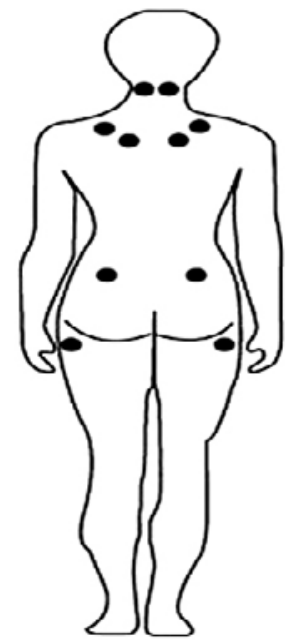

Patient number:

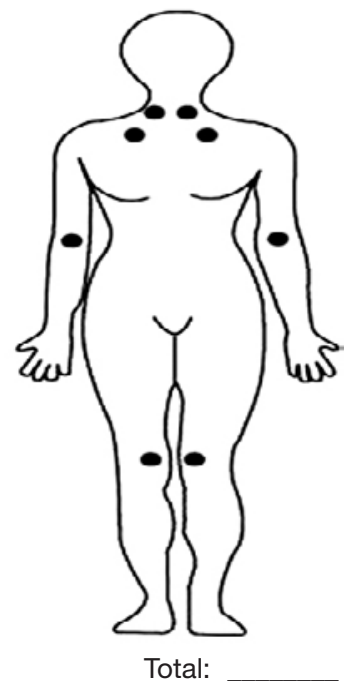

Figure 1. Fischer Algiometer measurement points (18 tender points)

\section{RESULTS}

Participated in the study 20 female patients, with mean age of 46.40 years with standard deviation of 10.615 years. Half of them were aged up to 48 years.

The effective group has shown statistically significant FIQ difference $(p>0.05)$ before and after treatment with decrease in the studied variable (Table 1 ).

Table 1. Fibromyalgia Impact Questionnaire results before and after treatment for both groups

\begin{tabular}{lccccc}
\hline $\begin{array}{l}\text { Descriptive } \\
\text { statistics }\end{array}$ & Minimum & Maximum & Median & Mean & $\begin{array}{l}\text { Standard } \\
\text { deviation }\end{array}$ \\
\hline $\begin{array}{l}\text { Sham group } \\
\text { Pre-treatment }\end{array}$ & 10.67 & 84.34 & 61.93 & 61.93 & 24.974 \\
Post-treatment & 12.67 & 85.20 & 47.65 & 42.42 & 28.241 \\
p=0.192 & & & & & \\
Effective group & & & & & \\
Pre-treatment & 31.19 & 76.49 & 55.53 & 55.36 & 14.018 \\
Post-treatment & 17.53 & 60.43 & 32.26 & 35.42 & 12.841 \\
p=0.005 & & & & & \\
\hline
\end{tabular}

There has been statistically significant difference $(\mathrm{p}<0.05)$ with regard to trigger-points measured values in the effective group (Table 2). 
Table 2. Values of the sum of trigger-points by Fischer Algiometer before and after treatment for both groups

\begin{tabular}{lccccc}
\hline $\begin{array}{l}\text { Descriptive } \\
\text { statistics }\end{array}$ & Minimum & Maximum & Median & Mean & $\begin{array}{c}\text { Standard } \\
\text { deviation }\end{array}$ \\
\hline $\begin{array}{l}\text { Sham group } \\
\quad \text { Pre-treatment }\end{array}$ & 30.60 & 78.10 & 48.85 & 49.92 & 14.093 \\
$\quad \begin{array}{l}\text { Post-treatment } \\
\quad\end{array}=0.556$ & 34.30 & 80.40 & 49.90 & 52.38 & 14.821 \\
$\begin{array}{c}\text { Effective group } \\
\quad \text { Pre-treatment }\end{array}$ & 28.00 & 59.60 & 48.30 & 46.24 & 10.733 \\
$\quad \begin{array}{l}\text { Post-treatment } \\
\text { p=0.037 }\end{array}$ & 31.30 & 74.00 & 54.45 & 53.14 & 14.008 \\
\hline
\end{tabular}

There has been statistically significant difference for the effective group $(\mathrm{p}<0.05)$ with regard to pain measured by VAS (Table 3).

Table 3. Pain intensity by the visual analog scale before and after treatment for both groups

\begin{tabular}{|c|c|c|c|c|c|}
\hline $\begin{array}{l}\text { Descriptive } \\
\text { statistics }\end{array}$ & Minimum & Maximum & Median & Mean & $\begin{array}{l}\text { Standard } \\
\text { deviation }\end{array}$ \\
\hline \multicolumn{6}{|l|}{ Sham group } \\
\hline Pre-treatment & 3.00 & 10.0 & 7.50 & 6.70 & 2.111 \\
\hline $\begin{array}{l}\text { Post-treatment } \\
p=0.277\end{array}$ & 2.00 & 9.00 & 6.00 & 5.60 & 2.503 \\
\hline \multicolumn{6}{|l|}{ Effective group } \\
\hline Pre-treatment & 2.50 & 9.00 & 6.00 & 6.05 & 2.061 \\
\hline $\begin{array}{l}\text { Post-treatment } \\
p=0.031\end{array}$ & 0.00 & 6.00 & 3.50 & 3.60 & 1.838 \\
\hline
\end{tabular}

There has been statistically significant difference in SF-36 domains $(p<0.05)$ for the Sham group (control), only on emotional aspects, with increased scores (Table 4).

Table 4. Scores of quality of life questionnaire domains before and after procedures for the Sham group

\begin{tabular}{|c|c|c|c|c|c|}
\hline $\begin{array}{l}\text { Descriptive } \\
\text { statistics }\end{array}$ & Minimum & Maximum & Median & Mean & $\begin{array}{l}\text { Standaro } \\
\text { deviation }\end{array}$ \\
\hline \multicolumn{6}{|l|}{ Functional capacity } \\
\hline Pre-treatment & 10.00 & 75.00 & 20.00 & 31.00 & 23.070 \\
\hline $\begin{array}{l}\text { Post-treatment } \\
p=0.120\end{array}$ & 10.00 & 95.00 & 32.50 & 38.00 & 26.895 \\
\hline \multicolumn{6}{|l|}{ Physical aspects } \\
\hline Pre-treatment & 0.00 & 100.00 & 0.00 & 22.50 & 36.228 \\
\hline $\begin{array}{l}\text { Post-treatment } \\
p=0.123\end{array}$ & 0.00 & 100.00 & 25.00 & 47.50 & 41.583 \\
\hline \multicolumn{6}{|l|}{ Pain } \\
\hline Pre-treatment & 40.00 & 90.00 & 60.00 & 62.00 & 13.166 \\
\hline $\begin{array}{l}\text { Post-treatment } \\
p=0.064\end{array}$ & 20.00 & 80.00 & 45.00 & 50.00 & 23.570 \\
\hline \multicolumn{6}{|c|}{ General health status } \\
\hline Pre-treatment & 30.00 & 80.00 & 62.50 & 59.00 & 15.420 \\
\hline $\begin{array}{l}\text { Post-treatment } \\
p=0.307\end{array}$ & 50.00 & 85.00 & 62.50 & 63.50 & 9.443 \\
\hline \multicolumn{6}{|l|}{ Vitality } \\
\hline Pre-treatment & 40.00 & 65.00 & 55.00 & 54.50 & 6.852 \\
\hline $\begin{array}{l}\text { Post-treatment } \\
p=0.142\end{array}$ & 45.00 & 80.00 & 55.00 & 58.00 & 10.055 \\
\hline
\end{tabular}

Table 4. Scores of quality of life questionnaire domains before and after procedures for the Sham group - continuation

\begin{tabular}{lccccc}
\hline $\begin{array}{l}\text { Descriptive } \\
\text { statistics }\end{array}$ & Minimum & Maximum & Median & Mean & $\begin{array}{l}\text { Standard } \\
\text { deviation }\end{array}$ \\
\hline $\begin{array}{c}\text { General aspects } \\
\quad \text { Pre-treatment }\end{array}$ & 25.00 & 75.00 & 50.00 & 50.00 & 15.590 \\
$\quad \begin{array}{l}\text { Post-treatment } \\
\text { p }=1\end{array}$ & 25.00 & 75.00 & 50.00 & 50.00 & 16.667 \\
Emotional aspects & & & & & \\
$\quad \begin{array}{l}\text { Pre-treatment } \\
\text { Post-treatment }\end{array}$ & 0.00 & 33.33 & 16.67 & 16.67 & 17.566 \\
$\quad$ p=0.033 & 0.00 & 100.00 & 66.67 & 60.00 & 43.886 \\
Mental health & & & & & \\
$\quad \begin{array}{l}\text { Pre-treatment } \\
\text { Post-treatment }\end{array}$ & 36.00 & 68.00 & 52.00 & 51.60 & 10.741 \\
p=0.399 & 36.00 & 68.00 & 54.00 & 54.00 & 11.963 \\
\hline
\end{tabular}

There has been evidence of statistically significant difference in SF-36 evaluation for the effective group $(\mathrm{p}<0.05)$ with regard to functional capacity, physical and emotional aspects, where patients after treatment have increased the respective indices (Table 5).

Table 5. Scores of quality of life questionnaire domains before and after procedures for the effective group

\begin{tabular}{|c|c|c|c|c|c|}
\hline $\begin{array}{l}\text { Descriptive } \\
\text { statistics }\end{array}$ & Minimum & Maximum & Median & Mean & $\begin{array}{l}\text { Standard } \\
\text { deviation }\end{array}$ \\
\hline \multicolumn{6}{|c|}{ Functional capacity } \\
\hline Pre-treatment & 20.00 & 65.00 & 50.00 & 48.00 & 16.364 \\
\hline $\begin{array}{l}\text { Post-treatment } \\
p=0.014\end{array}$ & 50.00 & 85.00 & 70.00 & 68.50 & 11.068 \\
\hline \multicolumn{6}{|l|}{ Physical aspects } \\
\hline Pre-treatment & 0.00 & 75.00 & 12.50 & 17.50 & 23.717 \\
\hline $\begin{array}{l}\text { Post-treatment } \\
p=0.008\end{array}$ & 0.00 & 100.00 & 75.00 & 75.00 & 31.180 \\
\hline \multicolumn{6}{|l|}{ Pain } \\
\hline Pre-treatment & 10.00 & 90.00 & 55.00 & 55.00 & 22.730 \\
\hline $\begin{array}{l}\text { Post-treatment } \\
p=0.289\end{array}$ & 10.00 & 70.00 & 40.00 & 43.00 & 18.288 \\
\hline \multicolumn{6}{|c|}{ General health status } \\
\hline Pre-treatment & 50.00 & 80.00 & 60.00 & 63.50 & 10.554 \\
\hline $\begin{array}{l}\text { Post-treatment } \\
p=0.523\end{array}$ & 40.00 & 75.00 & 55.00 & 58.00 & 11.106 \\
\hline \multicolumn{6}{|l|}{ Vitality } \\
\hline Pre-treatment & 30.00 & 60.00 & 45.00 & 46.50 & 10.014 \\
\hline $\begin{array}{l}\text { Post-treatment } \\
p=0.098\end{array}$ & 45.00 & 70.00 & 52.50 & 53.50 & 9.144 \\
\hline \multicolumn{6}{|l|}{ General aspects } \\
\hline Pre-treatment & 25.00 & 75.00 & 50.00 & 51.25 & 17.129 \\
\hline $\begin{array}{l}\text { Post-treatment } \\
p=0.429\end{array}$ & 12.50 & 62.50 & 50.00 & 47.50 & 15.366 \\
\hline \multicolumn{6}{|l|}{ Emotional aspects } \\
\hline Pre-treatment & 0.00 & 66.67 & 16.67 & 26.67 & 30.633 \\
\hline $\begin{array}{l}\text { Post-treatment } \\
p=0.013\end{array}$ & 0.00 & 100.00 & 100.00 & 80.00 & 35.833 \\
\hline \multicolumn{6}{|l|}{ Mental health } \\
\hline Pre-treatment & 44.00 & 68.00 & 54.00 & 53.60 & 8.044 \\
\hline $\begin{array}{l}\text { Post-treatment } \\
p=0.124\end{array}$ & 32.00 & 76.00 & 60.00 & 58.40 & 11.345 \\
\hline
\end{tabular}

Brain perfusion SPECT: significant changes in images 
Three effective group patients (Figure 2) had significant Brain Spect images changes with decreased biparietal hypoperfusion observed before tDCS and appearance of new hyperperfusion areas in basal ganglia after procedures. There have been no Brain Spect images changes for the Sham group.

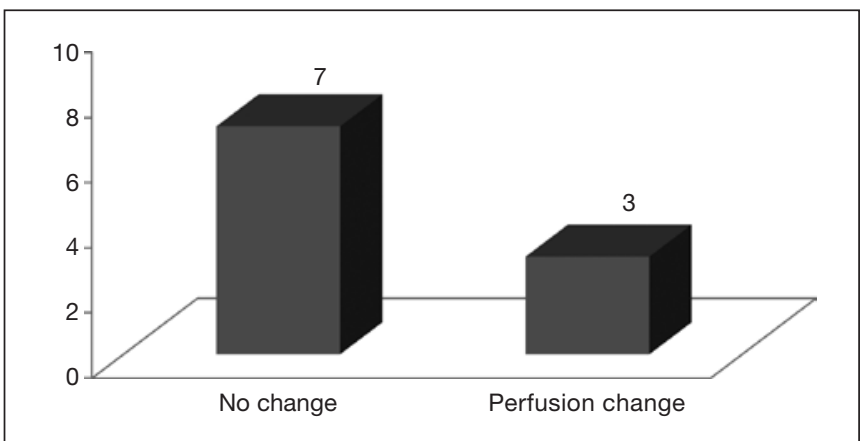

Figure 2. Significant Brain Spect images changes for the effective group after tDCS in 3 patients (30\%).

\section{DISCUSSION}

This scientific preliminary study with 20 female patients, with mean age of 46.40 years has shown statistically significant difference for the effective group in FIQ, VAS, Tender Points and SF-36 domains: Functional Capacity, Physical and Emotional Aspects, with improvement of such indicators as compared to the Sham group.

TDCS is a painless procedure causing just an occasional and transient itching sensation on skin below the electrodes. The application for 10-20 minutes of electric stimulation with intensity of 1 to $2 \mathrm{~mA}$ does not injure neural tissue ${ }^{13}$. Functional and neuro-image studies have shown that anodic tDCS is related to local blood flow change and does not cause edema or blood-brain barrier disorders which, in part, assures procedure safety ${ }^{6}$. Anodic stimulation induces significant increase in oxy-hemoglobin concentration while a negligible effect is observed on the cathode, confirming that electric stimulation reaches brain cortex in different ways ${ }^{14}$. tDCS is easy to apply and may be used as complementary strategy to control pain ${ }^{15}$. There is also a significant correlation of improvement in QL, evaluated by FIQ changes. The highest the score, the highest the impact on QL of individuals ${ }^{16}$. tDCS in this study, as compared to FIQ, has shown significant effectiveness in decreasing the negative disease impact on patients submitted to the treatment, as compared to the placebo group. There has been decrease of mean scores in the effective group from 55.36 to 35.42 , with expressive change in daily activities performance.

With regard to tender points, the sum of sensitivity scores found on Tender Points in this study has significantly increased for the effective group, with mean increase from 49.92 to 52.38. tDCS has significantly decreased hypersensitivity in these regions as compared to the placebo group. This satisfactory result was also found by other research centers. Randomized double-blind and controlled studies ${ }^{17,18}$ using transcranial stimulation have also shown significant pain intensity decrease in FM patients. A study ${ }^{19}$ has carried out a systematic review in journals such as Medline, PshychUNFO, CINAHL and Cochrane Library on the use of rTMS and tDCS to treat FM patients pain, and has found pain relief in $100 \%$ of studies with adequate scientific methodology using tDCS and in $80 \%$ of studies using rTMS.

VAS was representative to help checking pain intensity of patients of this study. tDCS in the effective group has considerably decreased pain intensity scores, with mean score decrease from 6.05 to 3.60 for patients submitted to stimulation, showing therapeutic benefits. According to Fregni et al. ${ }^{6}$, patients submitted to tDCS with active stimulation on M1 have also shown significant pain decrease by $\mathrm{VAS}^{6}$.

The SF-36 questionnaire is an extraordinary tool to evaluate $\mathrm{QL}^{20}$. tDCS with regard to SF-36 of this study has influenced factors related to functional, physical and emotional capacity, has promoted performance and QL improvement for the effective group, with mean score increase from 48.00 to 68.50 in functional capacity domain. In physical aspects there has been strengthening with mean score increase from 17.50 to 75.00 . In emotional aspects mean increase was from 26.67 to 80.00 . These data show QL improvement for patients submitted to tDCS. Similar results, however with $2 \mathrm{~mA}$ stimulation were also found by other research centers using EDCS in FM patients. Riberto et al. ${ }^{20}$, using similar procedures, have shown pain decrease and QL improvement. Fagerlund et al. ${ }^{21}$ have recently published that tDCS was effective to treat FM and the results of this study suggest that the therapeutic method has strong potential of inducing pain relief in FM patients.

FM patients may present changes in brain perfusion pat$\operatorname{tern}^{8,9}$. Brain Spect has been used in scientific research to study correlations of brain images in FM patients ${ }^{22}$. Eric Guedj of the Central Service of Biophysique et de Médecine Nucléaire in Assistance Publique dês Hôpitaux de Marseille and colleagues have investigated specific clinical correlations of functional brain abnormalities using SPECT. Twenty FM patients have presented frontal lobe, cingulated, temporal and cerebellar cortex hypoperfusion ${ }^{23}$. In our study, brain Spect evaluation of the effective group has suffered significant changes in brain perfusion in 3 patients, showing decreased biparietal hypoperfusion, observed before procedures, and appearance of new images with areas of hyperperfusion in basal ganglia after tDCS. Remaining results were inconclusive. The Sham group had no significant brain images changes.

\section{CONCLUSION}

tDCS was effective for therapeutic pain control and has promoted QL improvement for FM patients, because it represented a valid non-pharmacological option to treat FM. Brain Spect images deserve further studies for a better understanding of results. 


\section{REFERENCES}

1. Santos AM, Assumpção A, Matsutani LA, Pereira CA, Lage LV, Marques AP. Depressăo e qualidade de vida em pacientes com fibromialgia. Rev Bras Fisioter. 2006;10(3):317-24.

2. Weidebach WF. [Fibromyalgia: evidence of a neurophysiologic substrate]. Rev Assoc Med Bras. 2002;48(4):291. Portuguese.

3. Wolfe F, Clauw DJ, Fitzcharles MA, Goldenberg DL, Katz RS, Mease P, et al. The American College of Rheumatology preliminary diagnostic criteria for fibromyalgia and measurement of symptom severity. Arthritis Care Res. 2010;62(5):600-10.

4. Heymann RE, Paiva Edos S, Helfenstein M Jr, Pollak DF, Martinez JE, Provenza JR, et al. [Brazilian consensus on the treatment of fibromyalgia]. Rev Bras Reumatol. 2004;50(1):56-66. English, Portuguese.

5. Talelli P, Rothwell J. Does brain stimulation after stroke have a future? Curr Opin Neurol. 2006;19(56):543-50.

6. Fregni F, Gimenes R, Valle AC, Ferreira MJ, Rocha RR, Natalle L, et al. A randomized, sham-controlled, proof of principle study of transcranial direct current stimulation for the treatment of pain in fibromyalgia. Arthritis Rheum. 2006;54(12):3088-98.

7. Sokoloff L. Circulation and energy metabolism of the brain. In: Siegel GJ, Albert RW, et al. (editors): Basic Neurochemistry, $2^{\text {nd }}$ ed. Boston: Little Brown; 1972. 388-413p.

8. Mena GI. Neurospect: imagenología funcional em psiquiatría. Rev Med Nucl Alasbimn J. 2009;11(45):AJ45-1.

9. Mena I, Dörr A, Viani S, Neubauer S, Gorostegui ME, Dörr MP et al. Efectos del consumo de marihuana en escolares sobre funciones cerebrales demostrados mediante pruebas neuropsicológicas e imágenes de neuro-SPECT. Salud Ment. 2013;36(5):367-74.

10. Mena FJ, Mena I, Alamos F, Solé C, Neubauer S, Barra F, Garcia R. Children normal HMPAO brain SPECT. Alasbimn J. 1998;1(1):AJ01-3.

11. Withofs N, Bernard C, Van der Rest C, Martinive P, Hatt M, Jodogne S, et al. FDG PET/CT for rectal carcinoma radiotherapy treatment planning: comparison of functional volume delineation algorithms and clinical challenges. J Appl Clin Med Phys. 2014;15(5):4696.
12. Callegari SMJ. Bioestatística: princípios e aplicaçỏes. Porto Alegre: Artmed; 2003.

13. Roizenblatt S, Fregni F, Gimenez R, Wetzel T, Rigonatti SP, Tufik S, et al. Site-specific effects of transcranial direct current stimulation on sleep and pain in fibromyalgia: a randomized, sham-controlled study. Pain Pract. 2007;7(4):297-306.

14. Merzagora AC, Foffani G, Panyavin I, Mordillo-Mateos L, Aguilar J, Onaral B, et al. Prefrontal hemodynamic changes produced by anodal direct current stimulation. Neuroimage. 2010;49(3):2304-10.

15. Groppa S, Bergmann TO, Siems C, Möle M, Marshall L, Siebner HR. Slow-oscillatory transcranial direct current stimulation can induce bidirectional shifts in motor cortical excitability in awake humans. Neuroscience. 2010;166(4):1219-25.

16. Marques AP, Santos AM, Assumpçấo A, Matsutani LA, Lage LV, Pereira CA. Validação da Versão Brasileira do Fibromyalgia Impact Questionnaire (FIQ). Rev Bras Reumatol. 2006;46(1):24-31.

17. Mishkin MM. Contrast media safety: what do weknow and how do we know it? Am J Cardiol.1990;66(14):34F-36F.

18. Webb JA, Stacul F, Thomsen HS, Morcos SK. Late adverse reactions to intravascular iomedia. Eur Radiol. 2003;13(1):181-4.

19. Short EB, Borckardt JJ, Anderson BS, Frohman H, Beam W, Reeves ST, George MS. Ten sessions of adjuvantive left prefrontal TMS significantly reduces fibromyalgia pain: a randomized, controlled pilot study. Pain.2011;152(11):2477-84.

20. Riberto M, Marcon Alfieri F, Monteiro de Benedetto Pacheco K, Dini Leite V, Nemoto Kaihami H, Fregni F, et al. Efficacy of transcranial direct current stimulation coupled with a multidisciplinary rehabilitation program for the treatment of fibromyalgia. Open Rheumatol J. 2011;5:45-50.

21. Fagerlund AJ, Hansen OA, Aslaksen PM. Transcranial direct current stimulation as a treatment for patients with fibromyalgia: a randomized controlled trial. Pain. 2015;156(1):62-71

22. Marlow NM, Bonilha HS, Short EB. Efficacy of transcranial direct current stimulation and repetitive transcranial magnetic stimulation for treating fibromyalgia syndrome: a systematic review. Pain Pract. 2013;13(2)131-45

23. Camargo RS, Moser AD, Bastos LC. Abordagem dos métodos avaliativos em fibromialgia e dor crônica aplicada a tecnologia da informação: revisão da literatura em periódicos, entre 1998 e 2008. Rev Bras Reumatol. 2009;49(4):431-46. 